Int. J. Electrochem. Sci., 14 (2019) $651-661$

International Journal of

ELECTROCHEMICAL

SCIENCE

www.electrochemsci.org

\title{
Analysis on the Rapid Voltage Drop Based on a New Air-Cooled PEMFC Stack Design
}

\author{
Mingruo Hu*, Zhenpeng Li, Guangyi Cao \\ Green Electrochemical System and Structure Lab, Institute of Fuel Cell, \\ Shanghai Jiao Tong University, 800 Dong Chuan Road, Shanghai 200240, China \\ *E-mail: mingruohu@sjtu.edu.cn
}

doi: $10.20964 / 2019.01 .01$

Received: 1 July 2018 / Accepted: 20 August 2018 / Published: 30 November 2018

\begin{abstract}
A new structure called Membrane-Electrode-Assembly-Plate unit with lateral hydrogen tube is developed, which binding the periphery of the anode face of a bipolar plate with the periphery of the anode side of a membrane electrode assembly by using silicone adhesive. An air-cooled proton exchange membrane fuel cell stack is assembled through stacking forty Membrane-Electrode-Assembly-Plate units and mounting two hydrogen external manifolds. Consequently, the possibility of hydrogen leakage to the cathode side is excluded completely. The maximum power can temporarily reach $351.60 \mathrm{~W}$ at 20.0 A. Eight-hour stack stability is tested at a constant current of $4.77 \mathrm{~A}$, i.e., $100 \mathrm{mAcm}^{-2}$. The average voltage drop rate of single cell is calculated as $0.852 \mathrm{mVh}^{-1}$. It is explained that the rapid stack voltage drop during eight-hour operation is caused by the formation, accumulation and spread of liquid water inside both the anode and cathode gas diffusion layers and is reversible.
\end{abstract}

Keywords: air-cooled PEMFC stack; open-cathode; sealing; voltage drop; flooding

\section{FULL TEXT}

(C) 2019 The Authors. Published by ESG (www.electrochemsci.org). This article is an open access article distributed under the terms and conditions of the Creative Commons Attribution license (http://creativecommons.org/licenses/by/4.0/). 